\title{
THE EFFECTIVENESS OF ROLE-PLAY TOWARDS VOCATIONAL SCHOOL STUDENTS' SPEAKING SKILL
}

\author{
Bimantara Wicaksana $^{1}$, Enis Fitriani ${ }^{2}$, Munawwir Hadiwijaya ${ }^{3}$ \\ $(1,2,3)$ IKIP Budi Utomo Malang \\ 1bimantarabima53@gmail.com
}

\begin{abstract}
This study aimed at investigating the effectiveness of using role play toward speaking skill in learning English at the Class X students of SMKS Muhammadiyah Pangkalan Bun. Quasi experimental research was administered in this study, using two groups of experimental and control. Multimedia 1 class as the experimental group and Multimedia 2 class as the control group. There were six meetings for each group with four meetings for treatment, and other two meetings for pre-test and post-test. The data were in form of speaking scores emphasizing on fluency, structure, and bravery. From the t-test for independent samples, the result showed that the value of t-test was 0.034 less than 0.05 . It means that the result of posttest scores in experimental and control groups are significantly different. Then, from the comparison of the means between pretest and posttest of experimental and control groups, the experimental group's mean outperformed the control group in 2.20. It means that role play is effective in speaking skill in learning English. Furthermore, this study also showed that role play could create a communicative atmosphere in the classroom.
\end{abstract}

Key words: Effectiveness, Role Play, Speaking Skill, Vocational School

CPendidikan Bahasa Inggris FPISH IKIP BU Malang

\section{Introduction}

The perks of mastering speaking in learning English are countless. Speaking has distinctive purposes based on the goal of the speaker. For students, speaking could be defined as to spell the needs, such as asking and giving request, information, opinion, etc. (Brown, Yule, and McKelvie, 1986). The speaker says words to the listeners not only to express what he needs but also to obtain information or services.

Meanwhile, Jones (2001) stated that speaking is a means of communication. In communicating, people speak to give other as a sign that the speakers express their needs, such as asking or giving request, information, or services. Thus, as speakers, we must consider the persons we are talking to as listeners.

The activity that the person does is primarily based on a particular goal. This particular goal matters to be studied by students in Indonesia. As much as it importance as the function of speaking, then high school levels need to learn and practice how to speak English as a medium of communication.

The use of international languages such as English is already widespread, as well as in the world of vocational school. Moreover, English is a worthwhile subject to learn especially to find out the sources of knowledge on specific professions which mostly gained from international journals or books. This is beneficial for the vocational school students, because they still have plenty of time to learn and master English as their basis in before they enter to University and real life.

SMK as a vocational education institution seeks to prepare students to work according to their fields. Studying English for Multimedia in SMK is very important. It is due to English for Multimedia contains specific terms of Multimedia needed by the student. One of learning models that can be applied in teaching English is role play.

Wahab (2009: 109) mentioned that role playing is an act as the 
predetermined roles for certain purposes, such as living, job professions, and others. It is also supported by Hamdani (2011: 87), that role playing is a way for learners to master learning materials by imagination and appreciation. The imagination and appreciation is done by students playing the role of living figures or non-living objects. This technique is played by more than one student, and it depends on what role is played.

Similarly, Jackson confirmed that role play really helps students who are having difficulties to be active and able to communicate in the learning process at school in a way that does not pose worry. Besides, role play also benefitted educators in terms of how and when to provide feedback in the learning process as fun as possible for the students.

There were several researches focusing on role-play technique in teaching speaking skill (as in Liu, 2010; Phuetphon, Chayanuvat, and Sitthitikul, 2012; Munandar, Sukirlan, and Suka, 2013; Kumaran, 2017; Akmal, 2018), but there is still no research discussing its implementation on vocational school. They mentioned the findings quantitatively on the use of role play in speaking skill towards college students (Liu, 2010; Phuetphon, Chayanuvat, and Sitthitikul, 2012), junior high students (Akmal, 2018), general senior high school students (Munandar, Sukirlan, and Suka, 2013) and qualitatively described it, such as in Kumaran (2017). Thus, this research was conducted because the researcher wanted to investigate how effective the role play method to enhance students' speaking skill in vocational school, specifically administered in SMKS Muhammadiyah Pangkalan Bun.

This study was expected to put benefaction to English Language Teaching knowledge in terms of the use of role-play in teaching speaking, especially in vocational school. It is also expected to add useful information referred to the effectiveness of role-play towards speaking in vocational school, especially for the English teachers.

\section{Research Method}

Quasi experimental research was administered in this study, using two groups of experimental and control. Multimedia 1 class as the experimental group and Multimedia 2 class as the control group. Class X-MM1 consists of 28 students and so does X-MM2. Before the experiment applied, the researcher conducted pretest related to speaking in order to know the homogeneity entry of students' speaking skill.

There were six meetings for each group with four meetings for treatment, and other two meetings for pre-test and post-test. The data were in form of speaking scores emphasizing on fluency, structure, and bravery.

This study involving speaking test and scoring rubrics as the instruments of the research. Speaking tests were intended to measure students' speaking skill under the topic of recounting an experience. The tests consisted of two similar tests, those were pre-test and post-test. Pretest was done to know whether or not the class was homogenous and to see how far their ability in speaking recounting an experience.

This study was conducted on the second semester of class $X$, so that the topics covered in the speaking section, as well as the drafting of teaching scenario, were related to recount past events. The post-test was applied to measure the effectiveness of role-play method controlled by using the cues and information. In this study, the researcher's role was being the facilitator at the first and second meetings, after 
that the researcher was being the observer of students' group role-play.

In addition, the scoring rubrics were developed to obtain the students' speaking skill. The scoring was concerned on three components (adapted from Florente, 2019), namely fluency, structure, and bravery. The fluency measured the ability to speak 'nearnative' or minimal pauses. Then, the structure measured the amount of knowledge on how to use English grammar. The last, bravery was set up to measure how motivated a student in delivering the story until it is finished. Furthermore, each component is weighted according to the level of grade. The details of the scoring rubrics were described in Table 1, 2, 3, and 4.

Table 1. Scoring Level

\begin{tabular}{|c|c|c|c|}
\hline \multicolumn{3}{|c|}{ Category } & ore \\
\hline \multirow{4}{*}{\multicolumn{3}{|c|}{$\begin{array}{l}\text { Excellent } \\
\text { Good } \\
\text { Fair } \\
\text { Poor }\end{array}$}} & 100 \\
\hline & & & 79 \\
\hline & & & 69 \\
\hline & & & 50 \\
\hline \multicolumn{4}{|c|}{ Table 2. Criteria of Fluency Score } \\
\hline & Category & Explanation & Score \\
\hline Excellent & & $\begin{array}{l}\text { Near-native fluency } \\
\text { and uses } \\
\text { few to no pauses }\end{array}$ & $80-100$ \\
\hline Good & & $\begin{array}{l}\text { Good fluency with } \\
\text { occasional pauses to } \\
\text { think }\end{array}$ & $70-79$ \\
\hline Fair & & $\begin{array}{l}\text { Able to hold a } \\
\text { conversation } \\
\text { but sometimes uses } \\
\text { long pauses to think }\end{array}$ & $60-69$ \\
\hline Poor & & $\begin{array}{l}\text { Uses a lot long } \\
\text { periods of silence; } \\
\text { has difficulty } \\
\text { speaking in English }\end{array}$ & $<60$ \\
\hline
\end{tabular}

Table 3 Criteria of Structure Score

\begin{tabular}{|c|c|c|}
\hline Category & Explanation & Score \\
\hline Excellent & $\begin{array}{l}\text { Excellent used of } \\
\text { English Grammar }\end{array}$ & $80-100$ \\
\hline Good & $\begin{array}{l}\text { Good use of English } \\
\text { Grammar with } \\
\text { occasional mistakes }\end{array}$ & $70-79$ \\
\hline Fair & $\begin{array}{l}\text { Has basic knowledge } \\
\text { of English grammar } \\
\text { but grammatical } \\
\text { mistakes affects } \\
\text { comprehensibility }\end{array}$ & $60-69$ \\
\hline Poor & $\begin{array}{l}\text { Little knowledge of } \\
\text { how to use English } \\
\text { grammar }\end{array}$ & $<60$ \\
\hline
\end{tabular}

Table 4. Criteria of Bravery Score

\begin{tabular}{clc}
\hline Category & \multicolumn{1}{c}{ Explanation } & Score \\
\hline Excellent & $\begin{array}{l}\text { Motivated and eager to } \\
\text { start speaking in front }\end{array}$ & $80-100$
\end{tabular}




\begin{tabular}{|c|c|c|}
\hline & $\begin{array}{l}\text { of the class confidently } \\
\text { and finish the story } \\
\text { well }\end{array}$ & \\
\hline Good & $\begin{array}{l}\text { Motivated to come in } \\
\text { front of the class in less } \\
\text { confident way, but has } \\
\text { delivered the speaking } \\
\text { well }\end{array}$ & $70-79$ \\
\hline Fair & $\begin{array}{l}\text { Less motivated to come } \\
\text { in front of the class but } \\
\text { managed the speaking } \\
\text { well }\end{array}$ & $60-69$ \\
\hline Poor & $\begin{array}{l}\text { Hesitated and } \\
\text { unwillingly come in } \\
\text { front of the class, could } \\
\text { not finish the story }\end{array}$ & $<60$ \\
\hline
\end{tabular}

Adapted from https://idoc.pub/documents/role-play-grading-rubric-2nv8pw5oxolk with some revisions

The first step to analyse the data was done by scoring the students' speaking performance based on the scoring rubric as mentioned before. After that, the data were analysed using descriptive analysis to gain the data characteristics, such as maximum score, minimum score, and standard deviation of the score. Then, the data were analysed using Kolmogorov Smirnov in SPSS 22.0 version to find out the normal distribution of the scores.

After knowing the normality, the researcher looks for the t-value to know the significant difference of the values. If there is no significant difference, the next analysis on the post-test scores uses t-test for independent samples. But if the t-value is different, the next analysis uses ANCOVA.

Subsequently, the analysis was intended to answer the research problems, whether or not there is a difference in the mean of speaking score between students' who were taught by using role-play and those who were taught without using roleplay method.

\section{Result and Discussion}

The experimental group was given treatment by using role-play teaching and learning technique. It was considered as innovative in activating students' imagination in speaking. Furthermore, it did not need complicated materials. Moreover, the role-play applied in this study was in form of structured roleplay using cues and information. The students did not bother by the costumes and settings. They were just asking to pretend as the role they got. Whilst, the control group ran the usual teaching and learning activities for speaking recount text. They were drilled by the text, memorizing, and retold the previous story in front of the class. Even so, the post-test of both groups had the same instruction, that was the students were asked to retell the unforgettable memories happened during their first time studying at SMKS Muhammadiyah Pangkalan Bun. After the speaking performance was held, the post-test scores were gained and then were analyzed using ttest for independent group.

The difference of the means as obtained from the result of SPSS 22.0, showed that the value was .034 which was less than .05. It means the null hypothesis, namely there was no significant difference in the results of post-test scores of both experimental and control groups, was rejected. It could be concluded that there was a significant difference of the means 
between experimental and control groups.

To know the difference clearly, the researcher compared the post-test and pre-test scores of both experimental and control groups.

Table 5. The Comparison of the Post-test and Pre-test Scores of the Experimental and the Control

\begin{tabular}{lccccc}
\hline Groups & N & $\begin{array}{c}\text { Pre- } \\
\text { Test } \\
\text { Means }\end{array}$ & $\begin{array}{c}\text { Post- } \\
\text { test } \\
\text { Means }\end{array}$ & Gain & Sig. \\
\hline Experimental & 28 & 77.07 & 79.27 & 2.20 & .034 \\
Control & 28 & 75.90 & 76.86 & 0.96 & .034 \\
\hline
\end{tabular}

Table 5 shows that the pre-test mean of the experimental group (77.07) was higher than the pre-test mean of the control group (75.90). The post-test mean of the experimental group (79.27) was higher than the post-test of the control group (76.86). Both scores of the groups showed the gain of the means; as the experimental group gain was 2.20 and the control group gain was 0.96 . It meant that there were enhancement on the ability of the students in writing recount texts after experimentation was conducted. From the aforementioned findings, can be summed up that the experimental class performed higher than the control class. Thus, the role play technique is effective to be used in teaching speaking in vocational school.

The students' enhancement in speaking using role play teaching technique was supported by Liu (2010). Liu mentioned that a student should be able to express himself in the target language, especially in the basic interactions such as greetings, request information, services, and also retelling information or stories.

Role-play facilitates the demand because it offers a chance and imagination of 'being someone' in 'particular situation' using 'real-life communication'. Thus, in her study, Liu stated that communicative classroom activities could color and shape students' motivation and involvement in learning.

In line with what Liu has stated, this study also shows that role play facilitates the students in Multimedia class to express their imagination of 'being someone'. Being someone in this research varied as in being a computer sale that knows the specifications of laptops, and other things that related to the world of multimedia. Students were joyfully practice their roles. They made the script but not the whole script, so that they did not memorizing. They try to create the atmosphere of a shop, in an office, and also in holiday settings.

In addition, the role play was also exciting to be used in the experimental class since the students were getting bored with the reading and answering questions activities. So that, once the researcher asked the students to do roleplay, the whole class were excited and enthusiastic in dividing the roles to the group members. It affected the teacher to be more engaged with the students of $\mathrm{X}$ MM-1 Class. It also raised students' bravery to speak in front of the classroom, different from the conventional class which showed that the students were less enthusiastic in answering the questions and retelling a story in front of the class.

However, this study was not only showed the benefits of the study. It also explores the disadvantages of role play, 
such as teacher loses control over lesson, time constraints, inappropriate classroom management, incorrect grammatical production, and lack of purpose (Kumaran, 2017).

Based on the field note, this study agreed that teacher might lose control over lesson since in preparation step, students prefer to use their mother language instead of discussing the roles in English. Second, time constraints happened because the students need more times to be familiar with the topic and the role. However, it could be overcome by giving details and brief explanations about the topics and words used.

The researcher was hard to find other problems as proposed by Kumaran. The classroom management ran well because the role-play did not need much movements. Other than that, the grammatical issue also being the focus of this research. Yet, the grammar scores were covered with the fluency and students' bravery in speaking. Thus, it was not a big problem to deal with. The last disadvantages mentioned by Kumaran was lack of purpose. In this research, the purpose of carrying roleplay as well as the situation was focused on the purpose, because this research used structured role-play using cues and information. All in all, the teacher emphasized on recount text features that students should focus on.

\section{Conclusion}

The result of hypothesis testing using t-test for independent sample showed that the null hypothesis was rejected, with the value .034 less than .05 .

In summary, there is significant different of the students' speaking skill after treatment using role-play was applied. Role play is effective toward students' learning achievement in learning English at vocational school. It can be seen from the gained of the means of experimental group which is higher than the means of control group.

Based on the result of this study, it is suggested to the future researchers to make a well preparation in terms of speaking rubrics, instructions, topics, as well as the cues and information that are suitable with the students' entry level. It would help the implementation of the treatment during the research.

\section{References}

Akmal. (2018). The Effect of Role-Play Method In English Speaking Skill. Journal of Science and Social Research, 1(1), Online, http://jurnal.goretanpena.com/ind ex.php/JSSR/article/view/99/0, retrieved at May 2020.

Brown, G., Yule, G., \& McKelvie, N. (1986). Teaching the Spoken Language. RELC Journal, 17(1), 97-99.

https://doi.org/10.1177/00336882 8601700108

Florente, I., L. (2019). Role Play Grading Rubric. Online, https://idoc.pub/documents/roleplay-grading-rubric2nv8pw5oxolk, retrieved May 2020.

Hamdani. (2011). Strategi Belajar Mengajar. Bandung: Pustaka Setia.

Jackson, V.A., \& Back, A.L. (2011). Teaching communication skills using role-play: an experiencebased guide for educators. $\mathbf{J}$ Palliat Med, 14(6): 775-780. Online, doi:10.1089/jpm.2010.0493, retrieved on May 2020.

Jones, R. (2001). A ConsciousnessRaising Approach to the Teaching of Conversational Storytelling Skills. ELT Journal, 55(2), Pp: 155-169.

Kumaran, S., R. (2017). Benefits and Shortcomings of Role-Play as a 
Speaking Activity in English

Language Classrooms, The English Teacher. Online, https://journals.melta.org.my/ind ex.php/tet/article/view/273, retrieved on May 2020.

Liu, X. (2010). Arousing the College Students' Motivation in Speaking English through Role-Play. International Education Studies, 3(1), Online, http://www.ccsenet.org/journal/in dex.php/ies/article/view/4974, retrieved at May 2020.

Munandar, A., Sukirlan, M., and Suka, R. G. (2013). The Use of Role Play Technique in Improving Students' Speaking Ability. U-JET, 2(9), Online, http://jurnal.goretanpena.com/ind ex.php/JSSR/article/view/99/0, retrieved at May 2020.

Phuetphon, P., Chayanuvat, A., \& Sitthitikul, P. (2012). Using unscripted role play to improve speaking ability of Thai EFL students. Proceedings-Teaching Techniques-006 4th International Conference on Humanities and Social Sciences, Faculty of Liberal Arts, Prince of Songkla University, Hatyai, Thailand, Online, accessed on May 2020.

Wahab, A.A. (2009). Konsep Dasar IPS. Jakarta: Universitas Terbuka. 